Int. J. Dev. Biol. 59: 471-478 (2015)

doi: $10.1387 / \mathrm{ijdb} .150192 \mathrm{ao}$

\title{
Expression of Sox genes in tooth development
}

\author{
KATSUSHIGE KAWASAKI 1,2 , MAIKO KAWASAKI ${ }^{2}$, MOMOKO WATANABE ${ }^{1}$, ERIK IDRUS ${ }^{1,3}$, TAKAHIRO NAGAI ${ }^{1}$, \\ SHELLY OOMMEN ${ }^{2}$, TAKEYASU MAEDA ${ }^{1}$, NOBUKO HAGIWARA ${ }^{4}$, JIANWEN QUE${ }^{5}$, PAUL T. SHARPE*,2 \\ and ATSUSHI OHAZAMA*,1,2
}

${ }^{1}$ Division of Oral Anatomy, Department of Oral Biological Science, Niigata University Graduate School of Medical and
Dental Sciences, Niigata, Japan, ${ }^{2}$ Department of Craniofacial Development and Stem Cell Biology, Dental Institute,
King's College London, Guy's Hospital, London, UK, ${ }^{3}$ Division of Preventive Dentistry, Department of Oral Health
Science, Niigata University, Graduate School of Medical and Dental Sciences, ${ }^{4}$ Division of Cardiovascular Medicine,
UC Davis School of Medicine, Davis, CA, USA and ${ }^{5}$ Department of Medicine and Columbia Center for Human Development, Columbia University, New York, NY, USA

\begin{abstract}
Members of the Sox gene family play roles in many biological processes including organogenesis. We carried out comparative in situ hybridization analysis of seventeen sox genes (Sox 1-14, 17, 18, 21) during murine odontogenesis from the epithelial thickening to the cytodifferentiation stages. Localized expression of five Sox genes (Sox6, 9, 13, 14 and 21) was observed in tooth bud epithelium. Sox 13 showed restricted expression in the primary enamel knots. At the early bell stage, three Sox genes (Sox8, 11, 17 and 21) were expressed in pre-ameloblasts, whereas two others (Sox5 and 18) showed expression in odontoblasts. Sox genes thus showed a dynamic spatio-temporal expression during tooth development.
\end{abstract}

KEY WORDS: Sox, tooth development, in situ hybridization

Teeth develop from sequential and reciprocal interactions between epithelium and neural crest-derived mesenchyme. The first morphological sign of tooth development is an epithelial thickening on the first branchial arch. The thickened epithelium then progressively takes the form of the bud, cap and bell configurations. Primary enamel knots appear as thickened inner enamel epithelium at the early cap stage, but disappear by the late cap stage. Subsequently, epithelial cells differentiate into enamel-producing ameloblasts and dentin-producing odontoblasts differentiate from mesenchymal cells (dental papilla). It is known that many signaling pathways such as Bmp, Fgf, Wnt, and Shh play critical roles in regulating tooth development (Tucker and Sharpe, 2004).

Sox proteins are characterized by a highly conserved DNA binding motif, HMG (high mobility group) domain, and twenty Sox genes have been identified in mice. Members of the Sox gene family show dynamic and diverse expression patterns during development and mutation analyses in humans and mice provide evidence that they play multiple roles during development (Pevny and Lovell-Badge 1997, Hosking and Koopman 2008, Wegner 1999, Oommen et al., 2012). Sox2 has been shown to be expressed in rodent tooth germs including the incisor cervical loops (Ohazama et al., 2010; Juuri et al., 2012, 2013; Zhang et al., 2012). The expression of other members of Sox family in tooth development however remains unstudied.

We carried out comparative in situ hybridization analysis of sixteen Soxgenes (Sox1-14, 17, 18, 21) during murine odontogenesis, and reveal dynamic spatio-temporal expression of Sox 2, 4, 5, 6, $8,9,11,12,13,14,17,18$ and 21 in molar tooth development.

\section{Results}

Sox genes are classified into nine subgroups according to homology within the HMG domain and other structural motifs, as well as functional assays (Pevny and Lovell-Badge 1997, Wegner 1999).

\section{Group B}

Sox1, Sox2 and Sox3 belong to the B1 group of Sox family. Sox2expression has been shown in tooth development (Ohazama et al., 2010; Juuri et al., 2012, 2013; Zhang et al., 2012). Sox2 is expressed in tooth epithelium at the initiation stage (E10.5 and E11.5; Fig. 1 F,G). At the bud stage (E13.5) and the cap stage

Abbreviations used in this paper: E, embryonic day.

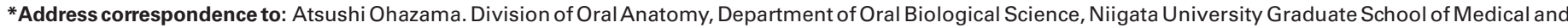

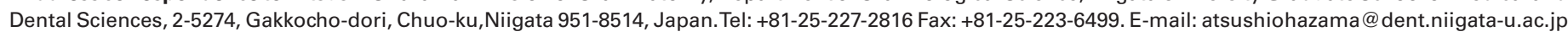
or PaulT. Sharpe. Department of Craniofacial Development \& Stem Cell Biology, Floor 27, Guy's Tower, Dental Institute, London Bridge, London SE1 9RT, UK. Tel: +44-20-7188-8038. Fax: +44-20-7188-1674. E-mail: paul.sharpe@kcl.ac.uk
}

Accepted: 18 June 2015.

ISSN: Online 1696-3547, Print 0214-6282 
(E14.5), Sox2 showed restricted expression in lingual bud epithelium (Fig. $1 \mathrm{H}, \mathrm{I}$ ). Significant expression of Sox2 is not found in tooth germs at E18.5 (Fig.1J). Although Sox1 and Sox3 belong to same group (B1) as Sox2, neither Sox1 nor Sox3 expression could be detected in tooth germs from E10.5 to E18.5 (Fig. 1 A-E, $1 \mathrm{~K}-\mathrm{O})$. Sox 14 and Sox 21 belong to the B2 group of Sox family. At the initiation stage, weak expression of Sox14 was observed in presumptive tooth epithelium, whereas Sox21 showed no expression (Fig. $1 \mathrm{P}, \mathrm{Q}, \mathrm{U}, \mathrm{V}$ ). At the bud stage (E13.5), Sox21 was weakly expressed in the collar of tooth bud epithelium, although no expression of Sox14 was observed in tooth germs (Fig. 1R,W). At the cap stage (E14.5), neither Sox14 nor Sox21 expression could be detected in tooth germs (Fig. 1S,X). At the cytodifferentiation stages (E18.5), weak Sox21 expression was observed in pre-ameloblasts localized at the presumptive cusp region, and Sox14 showed no expression in tooth germs (Fig. 1T,Y).

\section{Group $C$}

Sox4, Sox11 and Sox12 belong to the C group of Sox family. Sox4 and Sox 11 were expressed in presumptive tooth epithelium and mesenchyme at both E10.5 and E11.5, whereas Sox12showed no expression (Fig. 2 A,B,F,G,K,L). At E13.5, Sox4 was strongly expressed in tooth mesenchyme and the centre of bud epithelium, and Sox11 expression was observed in basal epithelium of tooth bud epithelium (Fig. 2C,H). Punctate expression of Sox12 was observed in both tooth epithelium and mesenchyme (Fig. 2M). At the cap stage, Sox4 was expressed in inner enamel epithelium, stellate reticulum, dental papillae and mesenchyme facing buccal outer enamel epithelium, whereas outer tooth enamel epithelium showed weak expression (Fig. 2D). Sox11 was expressed in the cervical loop of molar tooth epithelium and outer enamel epithelium, whereas Sox12 expression could not be detected in tooth germs at this stage (Fig. 2I,N). At cytodifferentiation stages, Sox11
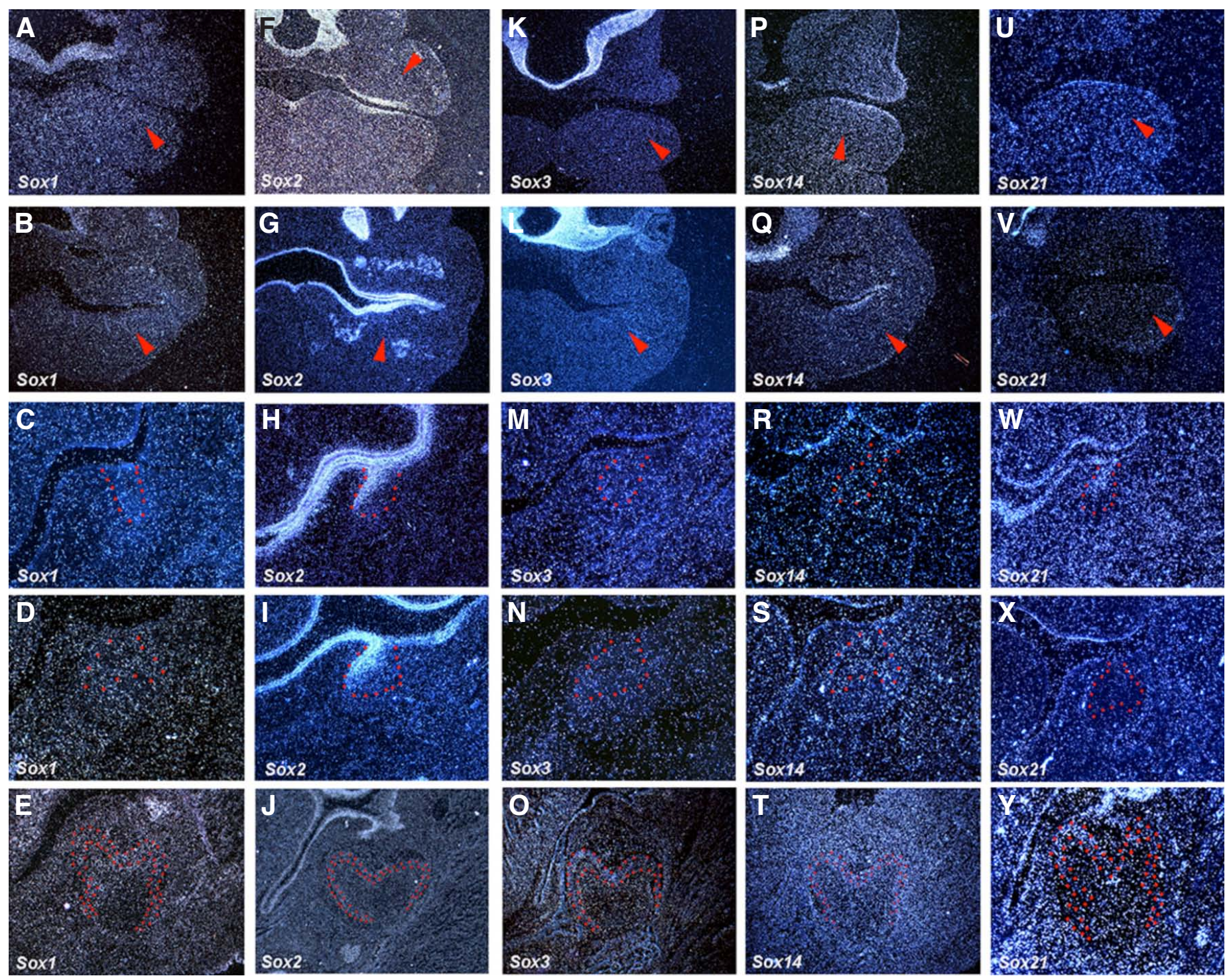

Fig. 1. The expression of Sox genes (Group B) in rodent tooth development. In situ hybridisation of Sox1, Sox2, Sox3, Sox14 and Sox21 on frontal head sections at E10.5, E11.5, E13.5, E14.5 and E18.5. Tooth epithelium is outlined in red. Arrowheads indicate the presumptive tooth region. 
expression was observed in pre-ameloblasts, whereas neither Sox4 nor Sox12 show expression in tooth germs (Fig. 2 E,J,O).

\section{Group D}

Sox5, Sox 6 and Sox 13 belong to the group D Sox genes. At E10.5, Sox5 showed restricted expression in tooth mesenchyme, whereas Sox6 and Sox13 expression were observed in both presumptive tooth epithelium and mesenchyme (Fig. 3 A,F,K). At E11.5, expression of Sox6 was observed in tooth epithelium, whereas Sox5 showed weak expression in mesenchyme (Fig. $3 \mathrm{~B}, \mathrm{G})$. Faint expression of Sox13 was observed in both tooth epithelium and mesenchyme at this stage (Fig. 3L). At the bud stage, Sox6 and Sox13 showed restricted expression in lingual bud epithelium and at the tip of bud epithelium, respectively (Fig. $3 \mathrm{H}, \mathrm{M})$. No expression of Sox 5 could be detected in tooth germs (Fig. 3C). At the cap stage, Sox5 was weakly expressed in dental papillae, whereas Sox13expression was observed in the primary enamel knot (Fig. 3 D,N). Sox6 showed restricted expression in lingual outer enamel epithelium (Fig. 3I). At cytodifferentiaton stages, Sox5 showed weak expression in dental papillae and odontoblasts, whereas neither Sox6 nor Sox13 were expressed in tooth germs (Fig. $3 \mathrm{E}, \mathrm{J}, \mathrm{O})$.
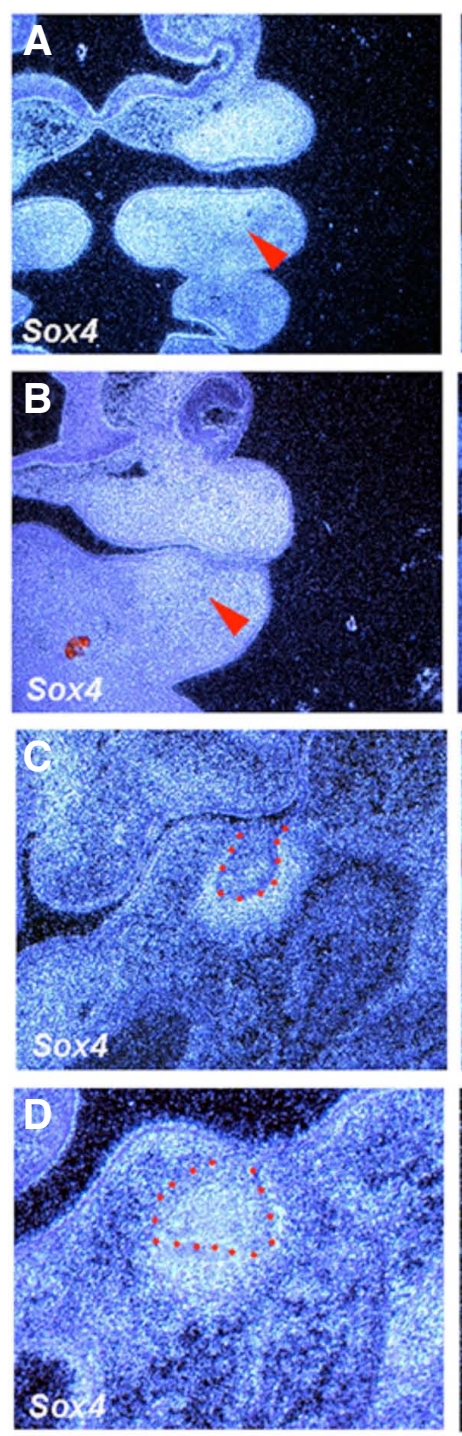

Fig. 2. The expression of Sox genes (Group C) in rodent tooth development. In situ hybridisation of Sox4, Sox11 and Sox12 on frontal head sections at E10.5, E11.5, E13.5, E14.5 and E18.5. Tooth epithelium is outlined in red. Arrowheads indicate the presumptive tooth region. Arrow indicates the presumptive alveolar bone region.

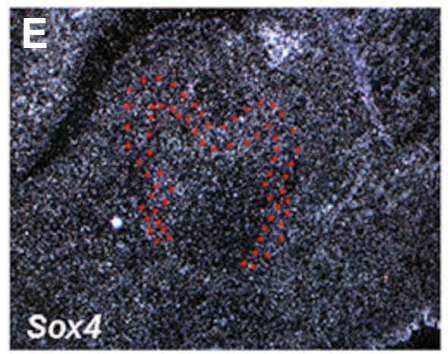

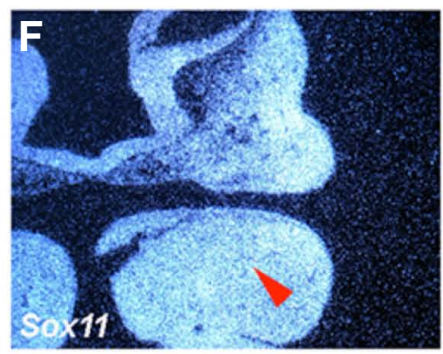
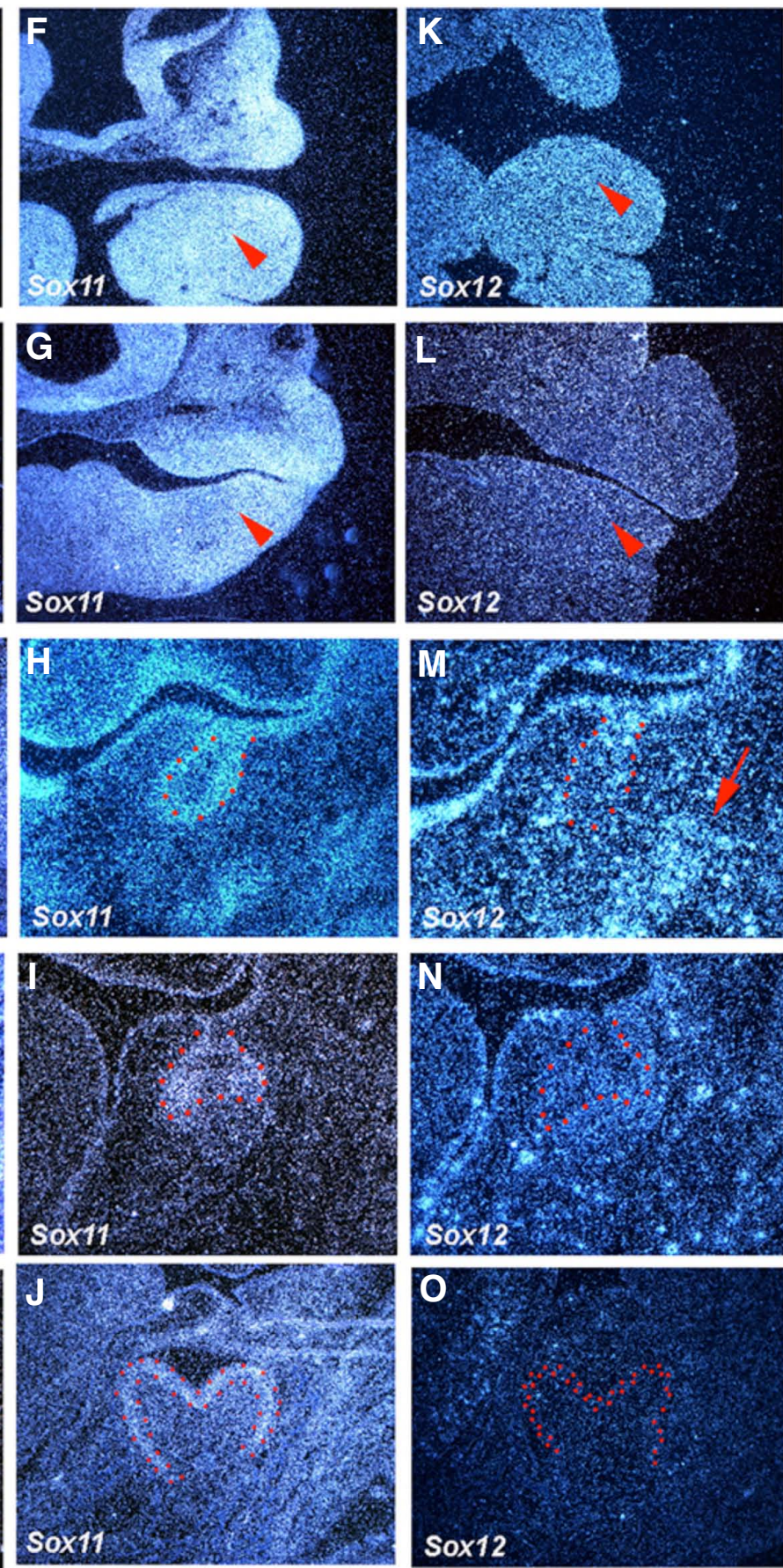
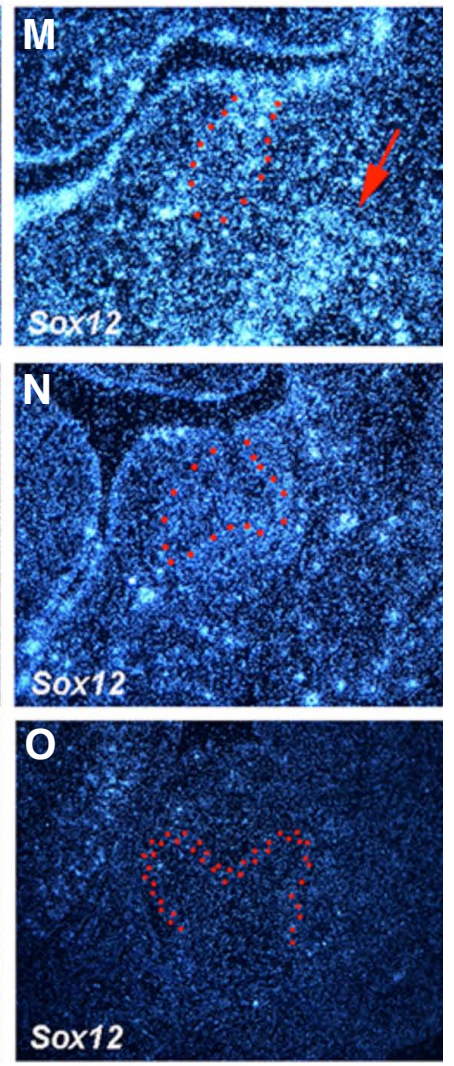

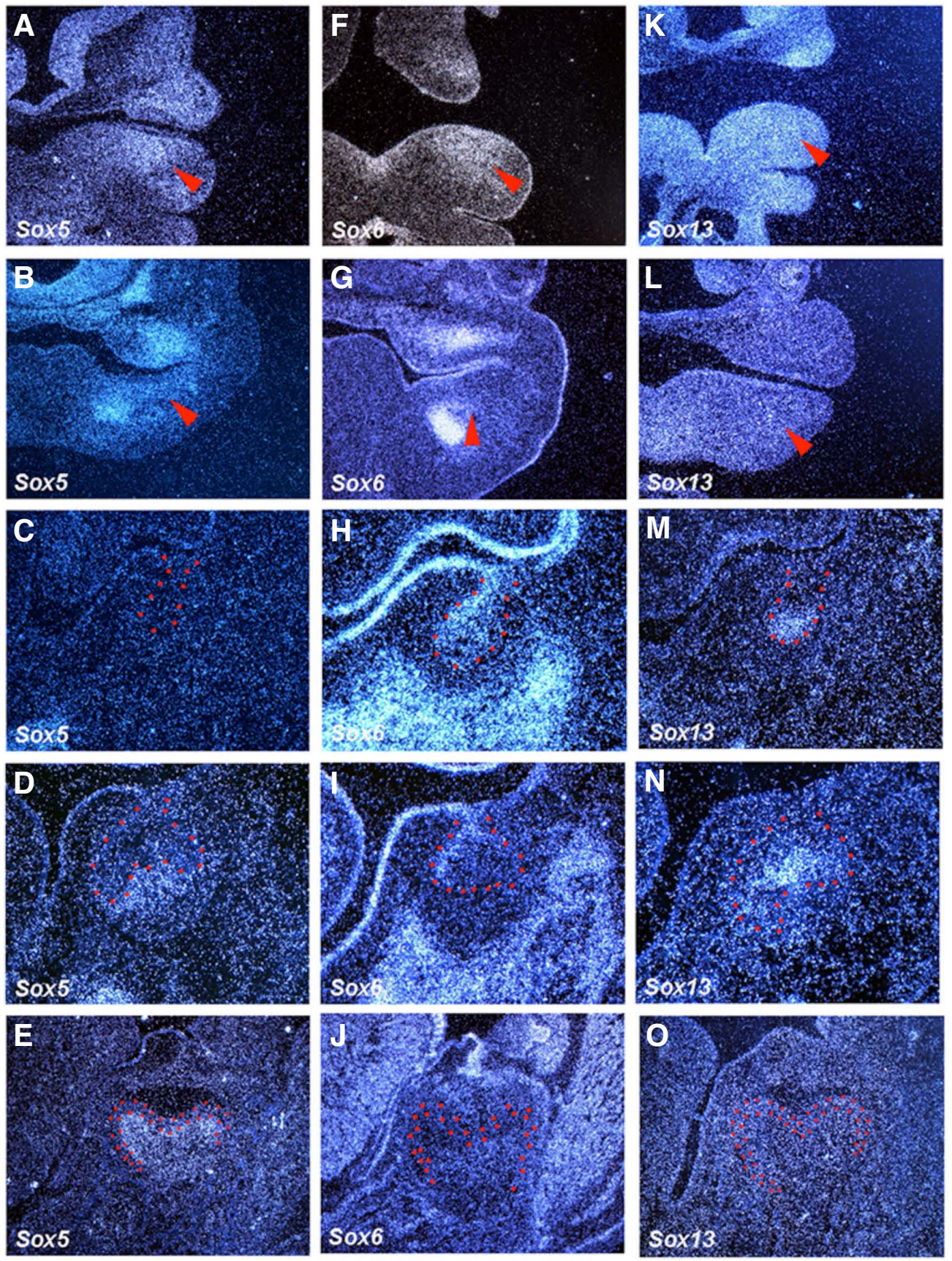

Fig. 3. The expression of Sox genes (Group D) in rodent tooth development. In situ hybridisation of Sox5, Sox6 and Sox13 on frontal head sections at E10.5, E11.5, E13.5, E14.5 and E18.5. Tooth epithelium is outlined in red. Arrowheads indicate the presumptive tooth region.

\section{Group E}

Sox8, Sox9 and Sox10belong to the group E Sox genes. Sox10 showed no expression in tooth germs from E10.5 to E18.5 (Fig. $4 \mathrm{~K}-\mathrm{O}$ ). Sox9 showed expression in both tooth epithelium and mesenchyme at E10.5, which became weak at E11.5 (Fig. 4 F,G, Mitsiadis et al., 1998). No expression of Sox8 could be detected in tooth germs at E10.5 or E11.5 (Fig. 4 A,B). At bud stage, Sox9 was weakly expressed in tooth epithelium, whereas no Sox8 expression was observed in tooth germs (Fig. 4 C,H). At the cap stage, weak expression of Sox8 was observed in inner enamel epithelium and dental papilllae, whereas Sox9 showed expression in outer enamel epithelium and collar of tooth epithelium (Fig. 4 D,I). At E18.5, weak expression of Sox8 was observed in preameloblasts, whereas Sox9 was expressed in rostral developing pulp and caudal stellate reticulum (Fig. 4 E,J).

\section{Group F}

Sox7, Sox17 and Sox18 belong to the group F Sox genes. A punctate expression pattern of Sox7 and Sox18 were seen throughout the mesenchyme at E10.5-E14.5 (Fig. 5 A-D, 5 K-N). 
Sox17showed similar expression, but weaker than those of Sox7 and Sox18 at these stages (Fig. 5 F-I). At E18.5, Sox17 was expressed in pre-ameloblasts, whereas Sox18 showed restricted expression in mesenchyme underneath presumptive cusp and facing cervical loops (Fig. $5 \mathrm{~J}, \mathrm{O}$ ). Sox7 showed no expression in tooth germs at E18.5 (Fig. 5E).

\section{Transgenic mice}

It has been shown that epithelial conditional Sox2mutation using ShhCre led to no significant changes of molars (Juuri et al., 2013).
In common with previous reports, significant anomalies could not be detected in molars in Sox2 mutants using K14Cre mice (Fig. $6 \mathrm{~B})$. To further analyze the role of Sox2 in tooth development, we examine mice overexpressing under the keratin 5 promoter (Krt5-Cre;Rosa26Sox2/+). However, no obvious differences could be detected in molar tooth germs in Krt5-Cre;Rosa26Sox2/+mice (Fig. 6C). Our data from in situ hybridization analysis shows Sox6 showed similar a expression pattern to Sox2 in tooth development (Fig. 1 F-J, 3 F-J). In order to investigate the role of Sox6 in tooth development, we examined Sox6 mutant mice $(\mathrm{p} 100 \mathrm{H}$
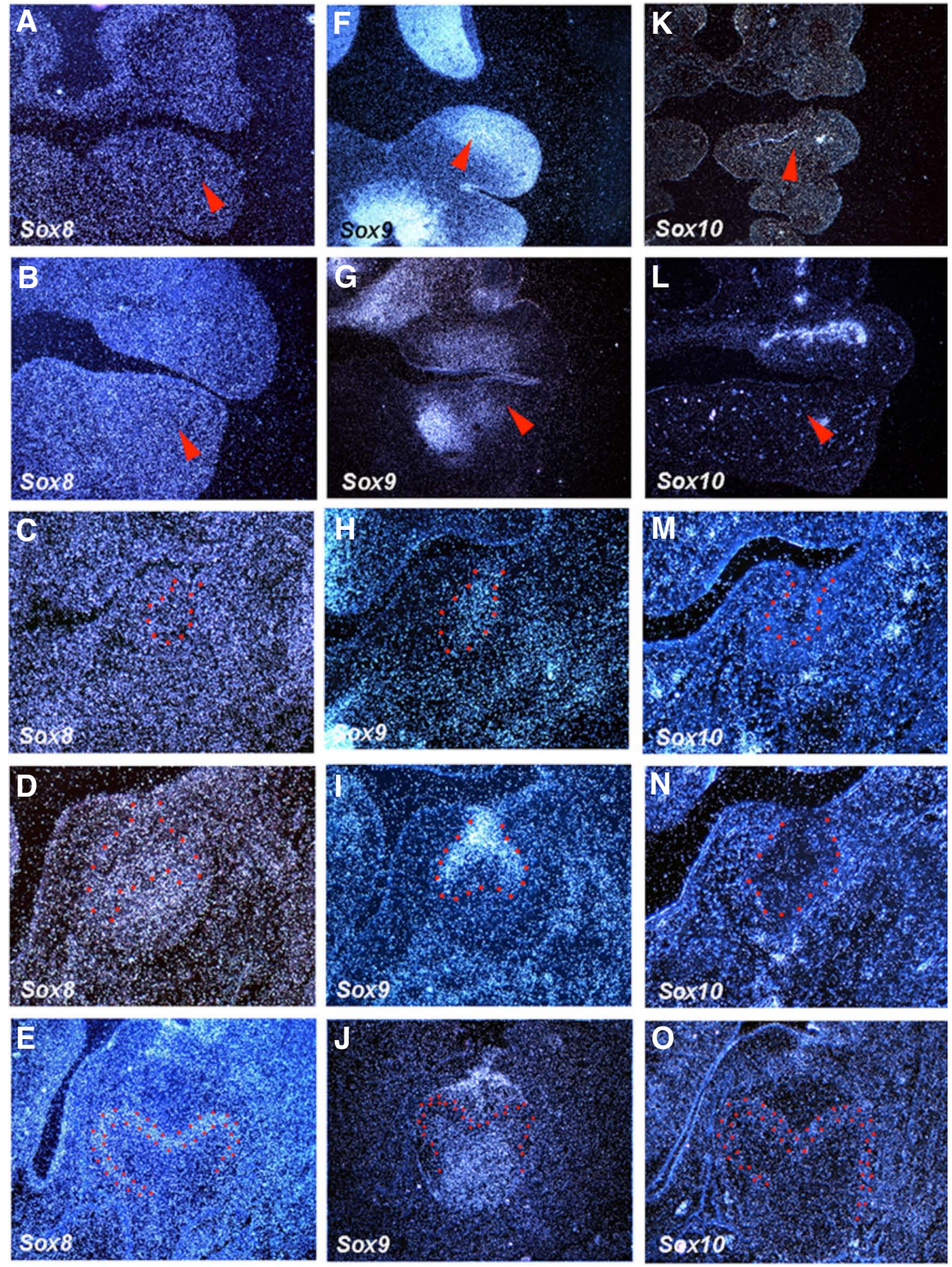

Fig. 4. The expression of Sox genes (Group E) in rodent tooth development. In situ hybridisation of Sox8, Sox9 and Sox 10 on frontal head sections at E10.5, E11.5, E13.5, E14.5 and E18.5. Tooth epithelium is outlined in red. Arrowheads indicate the presumptive tooth region. 
homozygotes). Significant differences however could not be detected in mutant molars (Fig. 6D).

\section{Discussion}

Members of the Sox gene family show dynamic and diverse expression patterns during development of many organs, and analysis of mutations in mice suggest that member of Sox gene family play multiple roles during development (Pevny and LovellBadge 1997). Our results also show dynamic spatio-temporal expression of Sox genes in developing tooth germs.

It has been shown that Sox2 plays a critical role in regulating molar dental lamina growth (Juuri et al., 2013). Sox2 is also expressed in the lingual bud and cap epithelium, although Sox2 mutant molars show no significant morphological changes (Juuri et al., 2013). We found that Sox6 have a similar expression pattern to Sox2 in tooth development. No siginificant anomalies however could be detected in Sox6 mutant molars. It has been shown that there is the redundancy between different Sox group members, and it is possible that Sox 2 function is compensated by Sox 6 in
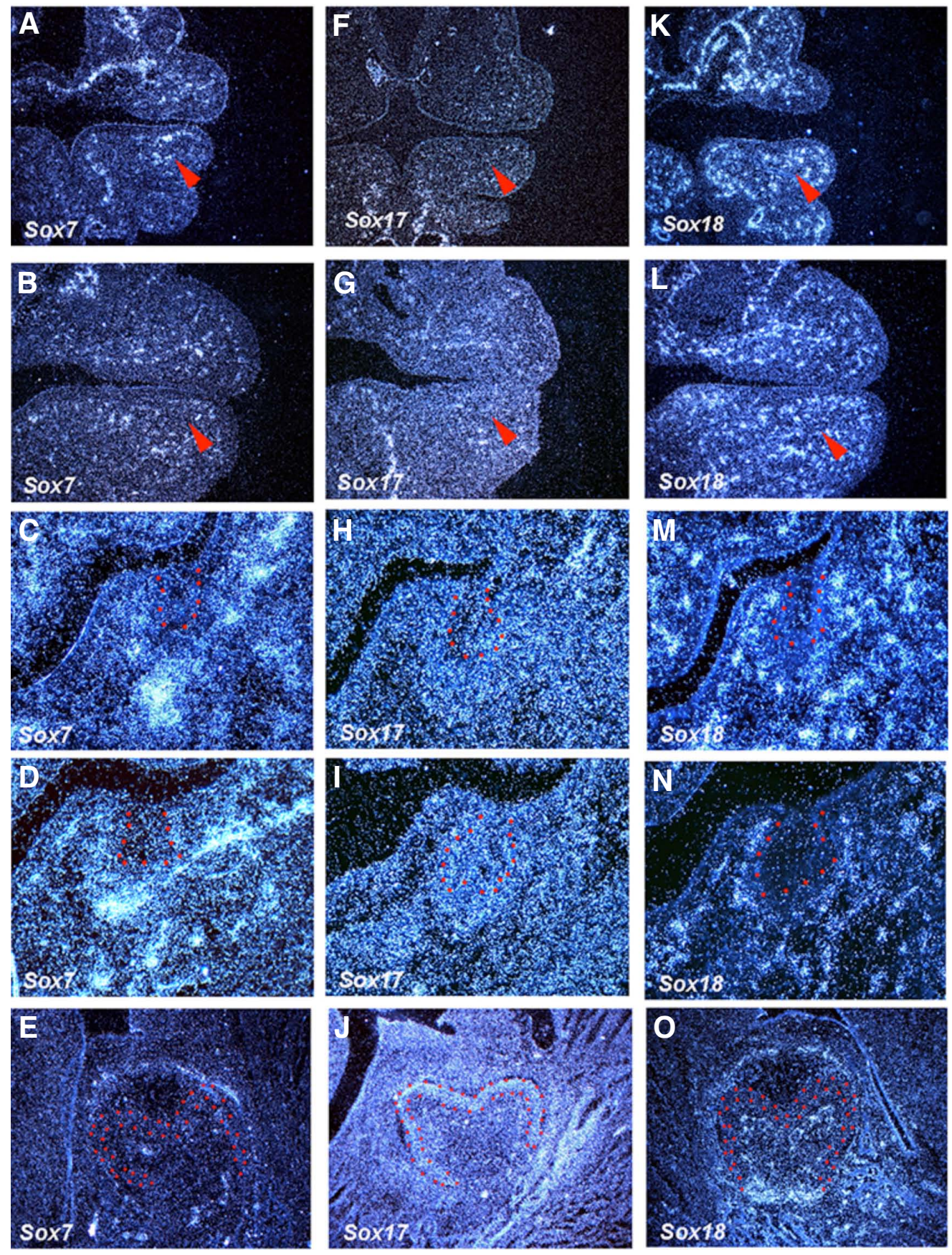

Fig. 5. The expression of Sox genes (Group F) in rodent tooth development. In situ hybridisation of Sox7, Sox 17 and Sox 18 on frontal head sections at E10.5, E11.5, E13.5, E14.5 and E18.5. Tooth epithelium is outlined in red. Arrowheads indicate the presumptive tooth region. 


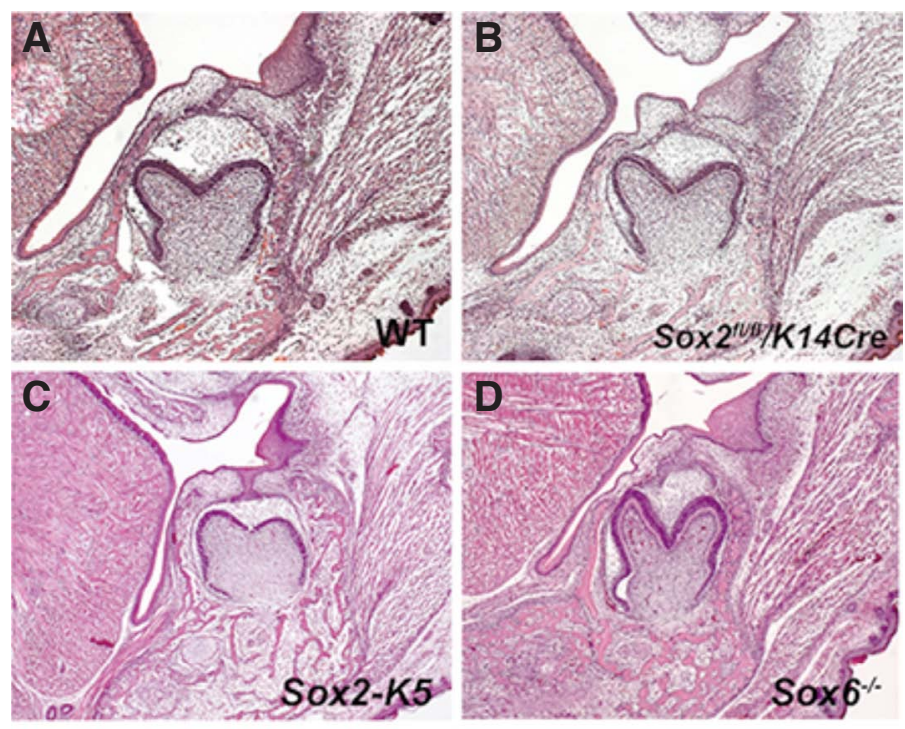

Fig. 6. Molar tooth phenotypes in Sox $2^{f / f l} ; K 14 C r e, K r t 5-$ Cre;Rosa26Sox2/+and Sox6mutant mice. Frontal sections showing the first lower molars of WT (A), Sox2 ${ }^{\mathrm{fl} / \mathrm{fl}} ; \mathrm{K} 14 \mathrm{Cre}$ (B), Krt5Cre;Rosa26Sox2/+ (C) and Sox6 (D) mice at E18.5.

molar tooth development (Ito 2010).

Oligodontia have been shown in patients with Sox5 haploinsufficiency (Lamb et al., 2012). We found that the expression of Sox 5 was observed in tooth mesenchyme at early stages of tooth development. Although the first tooth inductive signals are known to be derived from tooth epithelium at E9.5 and E10.5, mesenchymal cells provide signals back to the tooth epithelium at E11.5 (Ferguson et. al., 2000). Sox5 has been shown to be associated with Bmp and Shh signaling (Chimal-Monroy et al., 2003, Hojo et al., 2013). Both signaling pathways are known to be activated in tooth mesenchyme at early stages, and are essential for tooth development (Yang et al., 2014, Hardcastle et al., 1998, Li et al., 2011, Jeong et al., 2004). Sox5 might play a critical role in initiation of tooth development by regulating these signaling pathways.

The primary enamel knot is known to play a role in regulating tooth shape. Expression of many molecules including Shh have been identified in the primary enamel knots (Tucker and Sharpe, 2004). Our results showed the expression of Sox13 in the primary enamel knots, and Sox13 has been shown to be involved in Shh signaling (Katoh and Katoh 2008). It is possible that Sox13regulate tooth shape through involving Shh.

Sox18 mutations has been shown to result in the extensive detachment of developing oral epithelium from the underlying mesenchymal tissue due to abnormal hemidesmosome formation (Oommen et al., 2012). Abnormal teeth including enamel hypoplasia and extensive dental caries have been described in blistering diseases such as epidermolysis bullosa that is caused by disorder of hemidesmosomes (Kirkham et al., 2000, Wright et al., 1993). It is known that the interaction between odontoblasts, ameloblasts, and basement membrane play a critical role in enamel/dentin formation (Tucker and Sharpe 2004, Fukumoto et al., 2005). We found Sox18 expression in odontoblasts. It is possible that Sox18 is involved in enamel/dentin formation.

\section{Materials and Methods}

\section{Production and analysis of transgenic mice}

The production of mice with mutation of $\operatorname{Sox} 6(\mathrm{p} 100 \mathrm{H})$ have previously been described (Hagiwara et al., 2000). Krt5-Cre;Rosa26loxp-STOP-loxpSox2-IRES-eGFP (Krt5Cre;Rosa26Sox2/+), Keratin(K)14Cre and Sox2fl/ flmice were bred as described by Liu et al.,2013), Andl et al., (2004) and Teranova et al.,2006), respectively. CD1 mice were used for radioactive in situ hybridization. The day on which vaginal plugs were found was considered as embryonic day (E) 0.5 . To accurately assess the age of embryos, somite pairs were counted and the stage confirmed using morphological criteria such as relative size of maxillary and mandibular primordia, extent of nasal placode invagination, and the size of limb buds. Mouse heads were fixed in $4 \%$ paraformaldehyde, embedded and serially sectioned at $8 \mu \mathrm{m}$. Sections were split over 4-10 slides and prepared for histology and radioactive in situ hybridisation. Decalcification using 0.5M EDTA was performed after fixation of E18.5 mice.

\section{In situ hybridization}

Radioactive in situ hybridization with ${ }^{35}$ S-UTP-radiolabelled riboprobes was performed as described previously by Ohazama et al., 2008.

\section{Acknowledgments}

Y.O.-K. is supported by Nihon University. M.K. and K.K. are supported by JSPS International Program for Young Researcher Overseas Visits. This research was funded by grant NIH R01DK100342 and NYSTEM C029555 (J.Q), and the Japan Society for the Promotion of Science (JSPS; 26293421).

\section{References}

ANDL T, AHN K, KAIRO A, CHU EY, WINE-LEE L, REDDY ST, CROFT NJ, CEBRATHOMAS JA, METZGER D, CHAMBON P, LYONS KM, MISHINA Y, SEYKORA JT, CRENSHAW EB 3RD, MILLAR SE (2004). Epithelial Bmpr1a regulates differentiation and proliferation in postnatal hair follicles and is essential for tooth development. Development 31: 2257-2268.

CHIMAL-MONROY J, RODRIGUEZ-LEON J, MONTERO JA, GAÑANY, MACIAS D, MERINO R, HURLE JM (2003). Analysis of the molecular cascade responsible for mesodermal limb chondrogenesis: Sox genes and BMP signaling. Dev Biol 257: 292-301.

FERGUSON CA, TUCKERAS, SHARPE PT (2000). Temporospatial cell interactions regulating mandibular and maxillary arch patterning. Development 127: 403-412

FUKUMOTO S1, YAMADA A, NONAKA K, YAMADA Y (2005). Essential roles of ameloblastin in maintaining ameloblast differentiation and enamel formation. Cells Tissues Organs 181: 189-195.

HAGIWARA N, KLEWER SE, SAMSON RA, ERICKSON DT, LYON MF, BRILLIANT $\mathrm{MH}$ (2000). Sox6 is a candidate gene for $\mathrm{p} 100 \mathrm{H}$ myopathy, heart block, and sudden neonatal death. Proc Natl Acad Sci USA 97: 4180-4185.

HARDCASTLE Z, MO R, HUI CC, SHARPE PT (1998). The Shh signalling pathway in tooth development: defects in Gli2 and Gli3 mutants. Development 125:2803-2811.

HOJO H, OHBAS, TANIGUCHIK, SHIRAI M, YANO F, SAITOT, IKEDA T, NAKAJIMA $K$, KOMIYAMA Y, NAKAGATA N, SUZUKI K, MISHINA Y, YAMADA M, KONNO T, TAKATO T, KAWAGUCHI H, KAMBARA H, CHUNG UI (2013). Hedgehog-Gli activators direct osteo-chondrogenic function of bone morphogenetic protein toward osteogenesis in the perichondrium. J Biol Chem 288: 9924-9932.

HOSKING B, KOOPMAN P (2008). The SOX genes in development and disease. In: Epstein CJ, Erickson RP, Wynshaw-Boris A, eds. Inborn Errors of Development. pp. 883-893.

ITO M (2010). Function and molecular evolution of mammalian Sox15, a singleton in the SoxG group of transcription factors. Int J Biochem Cell Biol 42: 449-452

JEONG J1, MAO J, TENZEN T, KOTTMANN AH, MCMAHON AP (2004). Hedgehog signaling in the neural crest cells regulates the patterning and growth of facial primordia. Genes Dev 18: 937-951.

JUURI E, SAITO K, AHTIAINEN L, SEIDEL K, TUMMERS M, HOCHEDLINGER K, KLEIN OD, THESLEFF I, MICHON F (2012). Sox2+ stem cells contribute to 


\section{K. Kawasaki et al.}

all epithelial lineages of the tooth via Sfrp5+ progenitors. Dev Cell 23: 317-328.

JUURI E, JUSSILAM, SEIDEL K, HOLMES S, WU P, RICHMAN J, HEIKINHEIMO K, CHUONG CM, ARNOLD K, HOCHEDLINGERK, KLEINO, MICHONF, THESLEFF I (2013). Sox2 marks epithelial competence to generate teeth in mammals and reptiles. Development 140: 1424-1432

KATOH Y, KATOH M (2008). Hedgehog signaling, epithelial-to-mesenchymal transition and miRNA. Int $J$ Mol Med 22: 271-275.

KIRKHAM, J., ROBINSON, C., STRAFFORD, S.M., SHORE, R.C., BONASS, W.A., BROOKES, S.J. AND WRIGHT, J.T. (2000). The chemical composition of tooth enamel in junctional epidermolysis bullosa. Arch Oral Biol 45: 377-386.

KORMISH JD, SINNER D, ZORN AM (2010). Interactions between SOX factors and Wnt/beta-catenin signaling in development and disease. Dev Dyn 239: 56-68.

LAMB AN, ROSENFELD JA, NEILL NJ, TALKOWSKI ME, ET AL. (2012). Haploinsufficiency of SOX5 at 12p12.1 is associated with developmental delays with prominent language delay, behavior problems, and mild dysmorphic features. Hum Mutat 33: 728-40.

LI L1, LIN M, WANG Y, CSERJESI P, CHEN Z, CHEN Y (2011). Bmprla is required in mesenchymal tissue and has limited redundant function with Bmprlb in tooth and palate development. Dev Biol 349: 451-461.

LIU K, JIANG M, LU Y, CHEN H, SUN J, WU S, KU WY, NAKAGAWA H, KITA Y, NATSUGOE S, PETERS JH, RUSTGI A, ONAITIS MW, KIERNAN A, CHEN X, QUE J (2013). Sox2 cooperates with inflammation-mediated Stat3 activation in the malignant transformation of foregut basal progenitor cells. Cell Stem Cell 12: 304-315.

MITSIADIS TA, MUCCHIELLI ML, RAFFO S, PROUST JP, KOOPMAN P, GORIDIS C (1998). Expression of the transcription factors Ot|x2, Barx1 and Sox9 during mouse odontogenesis. Eur J Oral Sci 106 Suppl 1: 112-116.

MURUGANS, SHAN J, KÜHLSJ, TATAA, PIETILÄ I, KÜHLM, VAINIO SJ (2012). WT1 and Sox11 regulate synergistically the promoter of the Wnt 4 gene that encodes a critical signal for nephrogenesis. Exp Cell Res 318: 1134-1145.

NUMAKURAC, KITANAKAS, KATO M, ISHIKAWAS, HAMAMOTOY, KATSUSHIMA
Y, KIMURA T, HAYASAKA K. (2010) Supernumerary impacted teeth in a patient with SOX2 anophthalmia syndrome. Am J Med Genet A 152A: 2355-2359

OHAZAMA A, JOHNSON EB, OTA MS, CHOI HY, PORNTAVEETUS T, OOMMEN S, ITOH N, ETO K, GRITLI-LINDE A, HERZ J, SHARPE PT (2008). Lrp4 modulates extracellular integration of cell signaling pathways in development. PLOS One 3: e4092.

OHAZAMA A, HAWORTH KE, OTA MS, KHONSARI RH, SHARPE PT (2010). Ectoderm, endoderm, and the evolution of heterodont dentitions. Genesis 48: 382-389.

OOMMEN S, FRANCOIS M, KAWASAKI M, MURRELL M, KAWASAKI K, PORNTAVEETUS T, GHAFOOR S, YOUNG NJ, OKAMATSU Y, MCGRATH J, KOOPMAN P, SHARPE PT, OHAZAMA A (2012). Cytoplasmic plaque formation in hemidesmosome development is dependent on SoxF transcription factor function. PLoS One 7: e43857.

PEVNY LH, LOVELL-BADGE R (1997). Sox genes find their feet. Curr Opin Genet Dev 7: 338-344.

PORNTAVEETUS T, OHAZAMA A, CHOI HY, HERZ J, SHARPE PT (2012). Wht signaling in the murine diastema. Eur J Orthod 34: 518-524.

TARANOVA OV, MAGNESS ST, FAGAN BM, WU Y, SURZENKO N, HUTTON SR, PEVNY LH (2006). SOX2 is a dose-dependent regulator of retinal neural progenitor competence. Genes Dev 20: 1187-1202.

TUCKER A, SHARPE P (2004). The cutting-edge of mammalian development; how the embryo makes teeth. Nat Rev Genet 7: 499-508.

WEGNER M (1999) From head to toes: the multiple facets of Sox proteins. Nucleic Acids Res 27: 1409-1420.

WRIGHT, J.T., JOHNSON, L.B. AND FINE, J.D. (1993). Development defects of ename in humans with hereditary epidermolysis bullosa. Arch Oral Biol 38: 945-955.

YANG G, YUAN G, YE W, CHO KW, CHEN Y (2014). An Atypical Canonical Bone Morphogenetic Protein (BMP) Signaling Pathway Regulates Msh Homeobox 1 (Msx1) Expression during Odontogenesis. J Biol Chem 289: 31492-31502

ZHANG L, YUAN G, LIU H, LIN H, WAN C, CHEN Z (2012). Expression pattern of Sox2 during mouse tooth development. Gene Expr Patterns 12: 273-281. 


\section{Further Related Reading, published previously in the Int. J. Dev. Biol.}

Regional divergence of palate medial edge epithelium along the anterior to posterior axis Jiu-Zhen Jin, Dennis R. Warner and Jixiang Ding Int. J. Dev. Biol. (2014) 58: 713-717

http://www.intjdevbiol.com/web/paper/140094jd

Molecular signaling at the fusion stage of the mouse mandibular arch: involvement of insulin-like growth factor family Kazuya Fujita, Yuji Taya, Yoshihito Shimazu, Takaaki Aoba and Yuuichi Soeno

Int. J. Dev. Biol. (2013) 57: 399-406

http://www.intjdevbiol.com/web/paper/120110ys

Restoring physiological cell heterogeneity in the mesenchyme during tooth engineering Laetitia-Véronique Keller, Sabine Kuchler-Bopp and Hervé Lesot

Int. J. Dev. Biol. (2012) 56: 737-746

http://www.intjdevbiol.com/web/paper/120076hl

A non-enzymatic microsurgical dissection technique of mouse embryonic tissues for gene expression profiling applications Li Sun, May-Yin Lee and Jacqueline M. Veltmaat Int. J. Dev. Biol. (2011) 55: 969-974

http://www.intjdevbiol.com/web/paper/113424ls

Expression of Sox family genes in early lamprey development

Benjamin R. Uy, Marcos Simoes-Costa, Tatjana Sauka-Spengler and Marianne E. Bronner Int. J. Dev. Biol. (2012) 56: 377-383

http://www.intjdevbiol.com/web/paper/113416bu

The zebrafish sf3b1b460 mutant reveals differential requirements for the sf3b1 premRNA processing gene during neural crest development

Min An and Paul D. Henion

Int. J. Dev. Biol. (2012) 56: 223-237

http://www.intjdevbiol.com/web/paper/113383ma

Multiple effects of the cellular prion protein on tooth development

Yan Zhang, Seong-Oh Kim, Sibylle Opsahl-Vital, Sunita P. Ho, Jean-Baptiste Souron, Charles Kim, Kurt Giles and Pamela K. Den Besten

Int. J. Dev. Biol. (2011) 55: 953-960

http://www.intjdevbiol.com/web/paper/113348yz

5 yr ISI Impact Factor $(2013)=2.879$
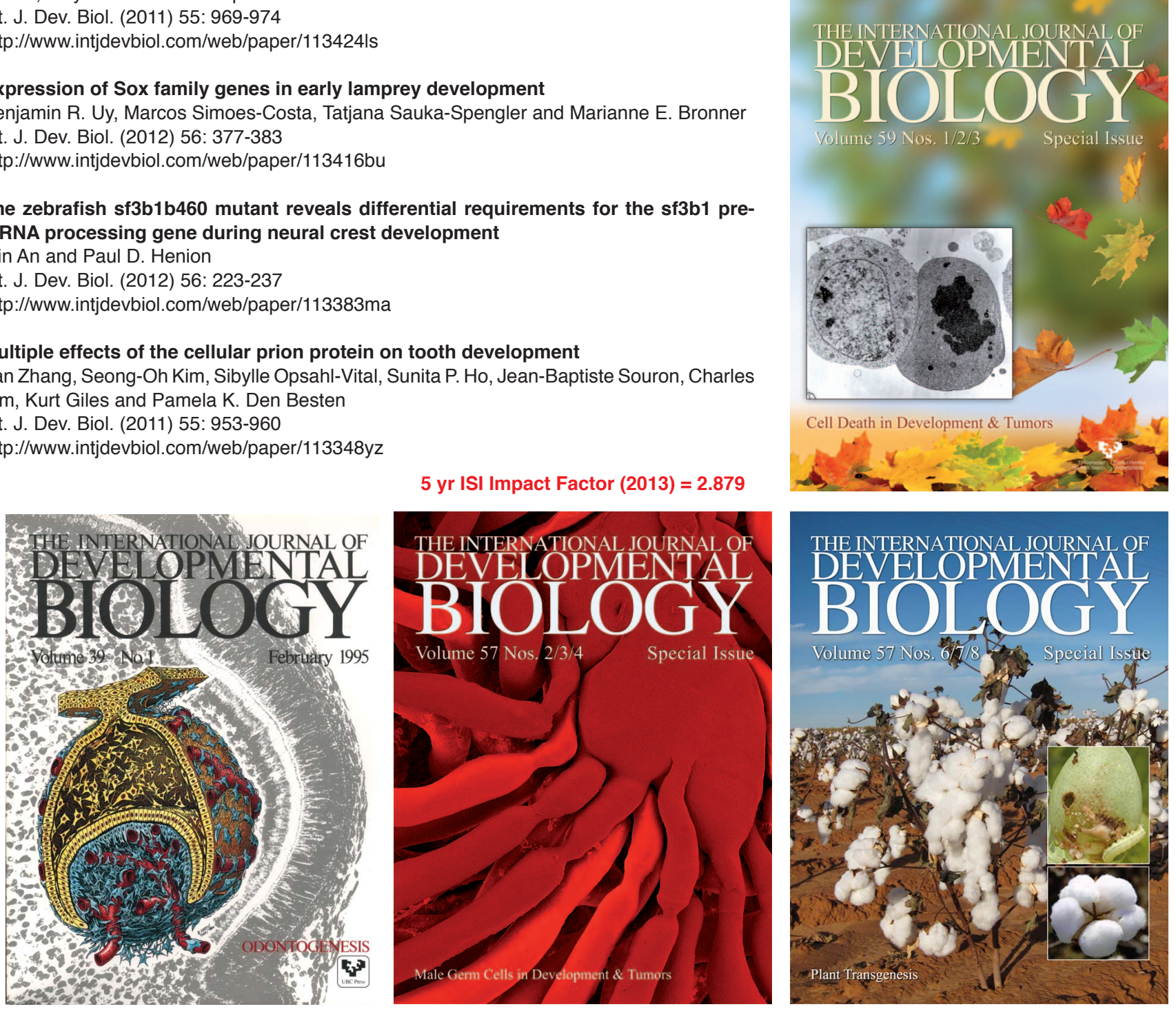